\title{
Prosodic Independence of Affixes in Brazilian Portuguese: an Experimental Approach
}

\author{
Camila Witt Ulrich, Luiz Carlos Schwindt \\ Federal University of Rio Grande do Sul, Brazil
}

\section{General overview}

In this paper we argue that Brazilian Portuguese (BP) affixes can be divided in (at least) two groups according to their prosodic behavior. The elements in the first group (e.g. pre-, -mento) constitute a prosodic word with the base, while the elements in the second group (e.g. pré-, -mente) behave as prosodic words in BP. The prosodic structure of forms like [pré][escola] or [béla][ménte] are similar to the one found in compounds like [guárda][chúva] or [pórta][lápis] - the reason for being designated as compositional affixes (SCHWINDT, 2000), in opposition to true affixes.

In general, true affixes do not present any level of autonomy. Compositional affixes, on the other hand, are attached to the stem/word (instead of the root) and tend to exhibit less morphosemantic dependence on the base, in addition to not being subject to several phonological processes proper to true affixes. By not being subject to some prosodic word domain processes, we consider they can be classified as independent prosodic words.

The main objective of this study is to find empirical evidence in the fields of phonetics, phonology and morphology to distinguish BP affixes in two prosodic categories. The questions which are investigated are two: (i) Can we find acoustic patterns in derived words - in special, duration - to differentiate true and compositional affixes? (ii) Are there psycholinguistic evidence to sustain that these two groups are accessed differently in our lexicon? Our hypothesis is that words derived by true affixes present characteristics of only one prosodic word - longer syllable in the stressed position (MASSINI, 1991; CANTONI, 2013) -, whereas words derived by compositional affixes present two prominences - one in the base (e.g. bélamente) and one in the affix (e.g. belaménte). Furthermore, we hypothesize that words formed by compositional affixes (e.g. pré-, -mente) require more activity for their processing than words with true affixes (e.g. pre-, -mento).

In order to test these hypotheses, we conducted two experimental paradigms. The first one is an acoustic analysis to compare acoustic parameters in these two different types of derived words in BP. We analyzed duration in syllables and V-V units and we concluded that, for this data, syllables showed increase in duration towards the stressed position for all conditions, while V-V units seem to differentiate the two types of morphological formations. The second one is an eye tracking experiment with a lexical decision task to describe the fixations, saccades and level of accuracy in relation to derived words and nonce words. Our main results show that the processing of words with compositional affixes requires more activity than the true ones, since in this condition the participants presented more time and less accuracy to complete the tasks.

The article is organized as follows. In section 2 we describe the reasons to differentiate true and compositional affixes and present our proposal for this last group; the details and results of the acoustic analysis and the eye tracking experiment are presented, respectively, in sections 3 and 4; in section 5, some further steps in order to improve and continue the analysis are commented.

\footnotetext{
* This study was financially supported by the International Cooperation Program - Brazil (CAPES) Finance Code 001 and by the National Council for Scientific and Technological Development (CNPq). We are thankful for the comments and suggestions of Linguistic Circle: Phonology and Morphology members at UFRGS, Phonology group members at University of Delaware and AMP abstract reviewers and participants. The authors can be contacted in camilawittulrich@gmail.com; schwindt@ufrgs.br.
} 


\section{Affixation in Brazilian Portuguese}

Brazilian Portuguese affixes can be classified in two distinct groups: true and compositional affixes. Based on the assumption that prosodic words can be smaller than morphosyntactic words (NESPOR; VOGEL, 1986), we assume that compositional affixes behave as prosodic words. This classification is attested by morphological characteristics of the affixes and by processes which only apply in the prosodic word. These processes and characteristics will be commented and exemplified in the next subsection.

2.1 Processes and characteristics to identify prosodic words in BP Based on previous works (especially LEE, 1995; MORENO, 1997; SCHWINDT, 2000/2008), we present below each of the criteria that may serve for the distinction between true and compositional affixes, followed by its explanation and an exercise of analysis with different affixes. These criteria are: (a) (in)dependence on the base, (b) attachment to the root/stem, (c) ordering, (d) (non) occurrence of vowel harmony, (e) (non) occurrence of assibilation, (f) (non) occurrence of velar softening, (g) final raising, (h) nasalization; (i) productivity and transparency; (j) change/preservation of vowel quality in the derived form.

(a) (In)dependence on the base

True affixes cannot be separated from their bases or instantiated in isolation; compositional affixes, on the other hand, seem to be independent on their bases, although they still depend on the context to ensure the right meaning.

Some PB prefixes may occur in isolation in the sentence, since they are inserted in some retrievable context. Also, their independence seems to present degrees of base integrity (or degrees of lexicalization). Examples of the phenomenon can be seen in (1a), but not in (1b):

\begin{tabular}{|c|c|}
\hline Prefix & Context \\
\hline bi- & A menina que me beijou é bi. (bissexual) \\
\hline & 'The girl who kissed me is "bi". (bissexual)' \\
\hline ex- & $\begin{array}{l}\text { O ex estava procurando a companheira. (ex-namorado / ex-mar } \\
\text { "The "ex" was looking for his partner. (ex-boyfriend / ex-husba }\end{array}$ \\
\hline vice- & $\begin{array}{l}\text { O vice participou do evento. (vice-governador / vice-presidente } \\
\text { "The "vice" has participated in the event. (vice governor / vice }\end{array}$ \\
\hline Prefix & Context \\
\hline $\mathrm{a}-$ & $\begin{array}{l}\text { Isso não é normal; é *a. (anormal) } \\
\text { 'This is not normal; it's *a (abnormal)' }\end{array}$ \\
\hline in- & $\begin{array}{l}\text { Ele parece muito *in. (infeliz) } \\
\text { 'He looks very *un. (unhappy)' }\end{array}$ \\
\hline re- & $\begin{array}{l}\text { Já fiz todo o trabalho, mas vou ter que *re. (refazer) } \\
\text { 'I have already done all the work, but I will need to *re. (redo) }\end{array}$ \\
\hline
\end{tabular}

What we can notice from these examples is that, for some affixes, specific lexical items are triggered in specific contexts - as it happens with bi-. In other cases, such as ex- and vice-, we are unsure about the specific lexical item, but we relate this isolated occurrence to a macrocategory usually attached to the affix, such as "ex-relation" regardless of it refers to a boyfriend or a husband, for example. However, it is worth noting that there are prefixes that are never instantiated in isolation, such as in-, a-, re-, for example.

With respect to suffixes, such independence is less common, given the lower lexical informativeness of the right edge of the word. In any case, sparse occurrences of suffixes in isolation are found.

b) Attachment to the root/stem

We assume that true affixes are attached to the root (e.g. cas- + -eiro $\rightarrow$ caseiro 'housekeeper'). In contrast, compositional affixes may be attached to the word after inflectional processes, such as in coração $_{\mathrm{SG}} \rightarrow$ corações $_{\mathrm{PL}} \rightarrow$ coraçõezinhos $_{\mathrm{PL}, \mathrm{DIM}}$, where the diminutive -zinho is inserted in the plural form of the word.

For prefixes, the morphological base cannot be presumed, since the left edge of the root and the word coincides. In an intratheoretical approach, one might think that prefixes that exhibit more independent behavior should attach to the theme, since they are in a different level of the derivation. 
Suffixes, on the other hand, since they are added to the inflectional edge of the base, give clues about the base of morphological attachment. BP roots are usually ended in a consonant, and, since most affixes are initiated by vowels, such as [cas]a/[cas]eiro or [camp]o/[camp]estre, there would not be sufficient reasons to postulate a theme vowel deletion rule for most of the BP lexicon ${ }^{1}$. There are, however, cases of suffixation that seem to extrapolate the boundaries of the morphological root.

The suffix -mente, for example, is attached to a base ending in -a, supposedly feminine, as in lindamente, belamente 'beautifully'. The suffix -zinho can be joined to forms already inflected in the plural, such as animaizinhos 'animals DIM' ' or coraçôezinhos (hearts ${ }_{\text {DIM }}$ ), recognized by the semivowel [j] or the diphthong /õeN/, present only in the pluralized form of the base.

Also, the discussion about the attachment to the inflected word can be extended to the affixes -inho and -íssimo, which are joined to the base after the attribution of feminine gender or plural information and, consequently, after the vocalic alternation of the root, as we see in the pairs s[o]gro / s[o]gros 'father-in-

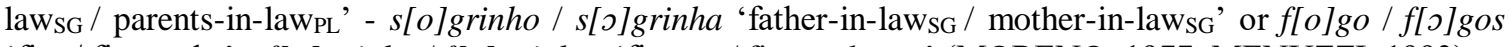
'fire / fireworks' - f[o]guinho / f[o]guinhos 'fire DIM / fireworksDim' (MORENO, 1977; MENUZZI, 1993).

c) Ordering

Portuguese can present two affixes of the same type in the resulting word. These two or more affixes may be both true or compositional. However, a compositional affix will never be more internal than a true affix. True affixes should be positioned closer to the root - as they are more dependent on the base - while compositional affixes should be positioned closer to the inflectional mark.

In a twofold prefixed word, as vice-copiloto 'vice copilot', we can assume that the two prefixes may be of the same type or that the prefix vice- is compositional and co- is true, not the opposite. The same is probably valid for reinadmitir 're-dismiss' or ex-corresponsável 'ex-co-responsible'. The only certain fact we have from the examples is that the prefixes in- or co- cannot be compositional unless re- and ex- are.

For twofold suffixed words, as adoravelmente 'adorably', the same analysis applies. We may suppose that they belong to the same class, or that at least -mente is compositional and -vel is true, but never the other way around. Although this criterion is not definitive, it gives us clues to a general analysis of class division.

Bachrach \& Wagner (2007) explain the prosodic independence of the diminutive forms in BP as a result of its syntactic attachment. For the authors, suffixes usually are heads of words; -inho and -zinho, on the other hand, are adjuncts, since they are more peripheral and they do not change the grammatical class of its base.

d) (Non) occurrence of vowel harmony

Vowel harmony, a variable phenomenon that occurs in the domain of the prosodic word (BISOL, 1981) in BP, consists in the raising of a pretonic mid vowel influenced mainly by the adjacent stressed vowel (e.g. $m[e] t \underline{i} d o \sim m[i] t \underline{i} d o$, 'meddlesome'). This process affects monomorphemic words (e.g. pepino, 'cucumber') or words derived by true affixes (e.g. metido, 'meddlesome'). According to Bisol (1981) and Schwindt (1995), independent affixes, like -inho/-zinho, for example, despite having a stressed high vowel, do not trigger vowel harmony (e.g. m[e]dinho $\sim *_{m}[i]$ dinho).

In (2), we analyze the behavior of vowel harmony in words derived by suffixes beginning with the vowel /i/ in a stressed and adjacent position to the mid vowel. The same blocking we mentioned above seems to apply to the suffix -íssimo.

\begin{tabular}{|c|c|c|}
\hline Suffix & Variable vowel harmony & Gloss, \\
\hline -ia & $\mathrm{p}[\mathrm{e}] \mathrm{dia} \sim \mathrm{p}[\mathrm{i}] \mathrm{dia}$ & 'ask PAST' \\
\hline -ido & $\mathrm{p}[\mathrm{e}]$ dido $\sim \mathrm{p}[\mathrm{i}]$ dido & 'askPTC' \\
\hline -ismo & cat $[\mathrm{e}] \operatorname{cismo} \sim \operatorname{cat}[\mathrm{i}] \mathrm{cismo}$ & 'catechism' \\
\hline -(i)nte & $\mathrm{p}[\mathrm{e}]$ dinte $\sim \mathrm{p}[\mathrm{i}]$ dinte & 'beggar' \\
\hline -inho & $\mathrm{m}[\mathrm{e}]$ dinho $-* \mathrm{~m}[\mathrm{i}]$ dinho & 'fear \\
\hline -zinho & $\operatorname{tr}[\mathrm{e}]$ nzinho $-* \operatorname{tr}[\mathrm{i}]$ nzinho & 'train \\
\hline
\end{tabular}

1 Some words derived by -al or -oso can present an intervening vowel between the root and the affix (e.g. racial 'racial', gracioso 'graceful'. However, these words constitute only 5\% of the words formed by these affixes in the BP lexicon, according to Schwindt (2013a). If compared to the general amount of suffixed words in the language, this number is highly decreased. 
-íssimo $\quad \mathrm{v}[\mathrm{e}]$ rdíssimo - *v[i]rdíssimo 'green ${ }_{S U P}$ '

Because vowel harmony is a process that occurs in pretonic syllables, prefixes are naturally excluded from the possible triggers to this phenomenon.

e) (Non) occurrence of assibilation

In $\mathrm{BP}$, the process of assibilation changes a stop into a sibilant ([t]> [s]) in derived words with suffixes beginning by [i] (LEE, 1995). For Farias (2012), "the coronal stops /t/ and /d/, as well as the velar stop /k/, turn into sibilant fricative [s] before the suffixes -ia, -idade, -ismo and -ista, all started by the high vowel /i/, such as dependente / dependência 'dependent' / 'dependency', prática / praticidade 'practical' / 'practicality', místico / misticismo 'mystical' / 'mystique"” (FARIAS, 2012, p. 9). The examples offered by the author are all of words formed by i-initial suffixes in stressed syllables, but -inho and -íssimo are not in the list. If you look closely to these affixes, they in fact does not seem to be subject to assibilation, preserving the base consonant, as in pacien/t/e $\rightarrow$ pacien/t/inho 'patient' / 'patient DIM' or al/t/o / al/t/íssimo 'high' / 'highsuP'. Like vowel harmony, this process does not involve prefixes, considering their position in the word.

f) (Non) occurrence of velar softening

Velar softening is an allomorphic process in which a velar stop /g/ becomes palatal fricative [3] before suffixes initiated by high vowels (LEE, 1995).

Faced with suffixes such as -ia or -ismo, for example, the phenomenon occurs, generating the derivations fonólo[g]o / fonolo[3]ia 'phonologist' / 'phonology' or diálo[g]o / dialo[3]ismo 'dialogue' / 'dialogism'. The process, however, does not apply with the affixes -inho and -íssimo (as pointed out by Lee, 1995). The same bases that served as examples in the previous case do not suffer allomorphy, as we see in the examples fonolo[g]inho 'phonologist ${ }_{\mathrm{DIM}}$ ', fonolo[g]íssimo 'phonologistsuP' or dialo[g]inho 'dialogue

Again, because the process causes consonant change by the influence of a following vowel, it does not happen at the left edge of the word, excluding prefixes.

\section{g) Final raising}

Final raising, a process which results from the neutralization between mid and high vowels in the final unstressed position of the word, is very common in BP. Rare are the dialects that still preserve mid vowels in the end of the word with some representative proportion. The domain of application of this process is the prosodic word and, therefore, its occurrence is capable of revealing prosodic word boundaries, even when there are no boundaries between morphological words.

At the left edge of the word, the final vowel of the prosodically independent prefix may be raised, as we see in (3). With true prefixes, however, raising does not happen.

\begin{tabular}{|c|c|c|}
\hline $\begin{array}{l}\text { Prefix } \\
\text { auto- } \\
\text { hipo- } \\
\text { macro- } \\
\text { micro- } \\
\text { mono- } \\
\text { neo- } \\
\text { pseudo- } \\
\text { vice- }\end{array}$ & 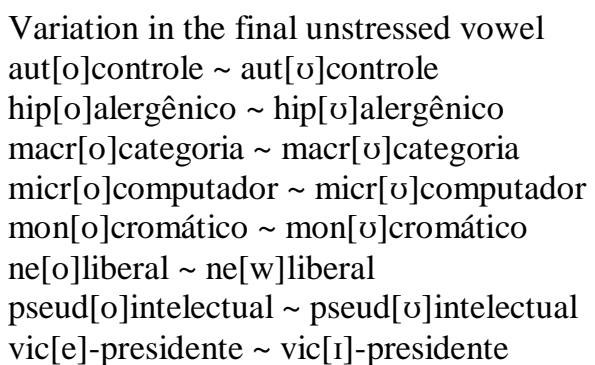 & $\begin{array}{l}\text { Gloss } \\
\text { 'self-control' } \\
\text { 'hypoallergenic' } \\
\text { 'macrocategory' } \\
\text { 'microcomputer' } \\
\text { 'monochromatic' } \\
\text { 'neoliberal' } \\
\text { 'pseudointellectual' } \\
\text { 'vice-president' }\end{array}$ \\
\hline
\end{tabular}

Regarding the right edge, such a process is not so informative, since most suffixes are vowel-initiated and are attached to the morphological root, as we argued in topic (b).

h) Nasalization

Bachrach and Wagner (2007) show that, when the stressed vowel of the base is nasal, the maintenance of nasalization in the derived word is categorical when we have evaluative suffixes, as in $c[\tilde{a}] m a-$ $c[\tilde{a}]$ minha - *c[a]minha 'bed', 'bed DIM'. However, it is variable when we have true suffixes, as in $c[\tilde{a}]$ mareira c[a]mareira 'room maid'. Again, it seems that the base does not suffer influence of the 
independent suffix on its segments, since they are different prosodic domains.

i) Productivity and transparency

Regarding the left edge, we see the integration of the prefix with the base or its morphosemantic independence through vowel quality. Between $\operatorname{pr}[\mathrm{e}]-$ and $\operatorname{pr}[\varepsilon]-$ prefixes, we see differences in meaning, transparency and productivity. While the word preconceito 'prejudice', for example, seems to carry a unique sense already crystallized, the word pré-conceito 'preconception' transparently carries the union between the property of the prefix (anteriority) and the meaning of the base. The same happens in derivatives with other prefixes with low-mid vowels, as pós- and pró-. For compositional suffixes, though we cannot distinguish two meanings according to this same criterion, we may consider them as productive formations, since they can be attached to diverse grammatical classes and do not present many constraints to its attachment (LEE, 1995).

j) Change/preservation of vowel quality in the derived form

As the strongest argument for prosodic independence, we mention the vowel raising resulting from the loss of distinction between low-mid and high-mid vowels in unstressed positions - positional neutralization (TRUBETZKOY, [1939] 1969). In dialects of southern Brazil, low-mid vowels / / / and / / never occur in unstressed positions, what causes a reduction in the vowel inventory.

\begin{tabular}{|c|c|c|c|c|}
\hline & \multicolumn{2}{|c|}{ stressed position } & \multicolumn{2}{|c|}{ unstressed position } \\
\hline & front & back & front & back \\
\hline high & $\mathrm{i}$ & $\mathrm{u}$ & $\mathrm{i}$ & $\mathrm{u}$ \\
\hline high-mid & & $\mathrm{o}$ & & o \\
\hline low-mid & & ○ & & \\
\hline low & & & & \\
\hline
\end{tabular}

Chart 1 - Southern BP vowels for stressed and unstressed positions, according to Camara Jr. (1975, p. 41)

Therefore, in these dialects there is a difference between the vowel quality of the base and the derived form (e.g. /'be.lo/ / /be.'le.za/, not /be.'le.za/, 'beautiful' / 'beauty') due to the addition of syllables and, consequently, the change of the primary stress site.

This change does not occur in words derived by -inho, -zinho, -mente and -íssimo (and, in some cases, by -ão and -ona), as in the examples $b[\varepsilon] l o, b[\varepsilon]$ linho, $b[\varepsilon]$ lozinho, $b[\varepsilon]$ lamente and $b[\varepsilon] l i s s i m o, t[\varepsilon] l a \tilde{o}$ and $t[\varepsilon] l o n a$. Taking into account that the seven vowels are constrastive only in stressed positions in BP, being the distinction between mid vowels neutralized (e.g. $b[e] l e z a \sim b[\varepsilon] l e z a$ ), and the fact that low-mid vowels are restricted to stressed contexts in some dialects (like in Southern Brazil), we sustain that these affixes constitute, regardless of their bases, independent prosodic words.

If we look at BP suffixes, we see that this raising happens in the vast majority of derivations.

\begin{tabular}{|c|c|c|}
\hline Base + suffix & Derived form & Gloss \\
\hline $\mathrm{b}[\varepsilon] \mathrm{lo}+-\mathrm{eza}$ & $\mathrm{b}[\mathrm{e}] \mathrm{leza}$ & 'beauty' \\
\hline $\operatorname{caf}[\varepsilon]+-\mathrm{al}$ & caf $[\mathrm{e}] \mathrm{zal}$ & 'coffee plantation' \\
\hline $\operatorname{pat}[\varepsilon] \mathrm{rno}+$-idade & pat[e]rnidade & 'paternity' \\
\hline $\mathrm{n}[\mathrm{o}] \mathrm{va}+$-iça & $\mathrm{n}[\mathrm{o}] \mathrm{viça}$ & 'novice' \\
\hline $\mathrm{s}[0] 1+-\mathrm{aço}$ & $\mathrm{s}[\mathrm{o}] \mathrm{laço}$ & 'strong sunlight' \\
\hline $\mathrm{m}[\mathrm{o}] \mathrm{da}+$-ismo & $\mathrm{m}[\mathrm{o}]$ dismo & 'fad' \\
\hline
\end{tabular}

This is not the case with evaluative suffixes (diminutive, superlative - and perhaps augmentatives) and the adverbial suffix.
Base + suffix
Derived form
Gloss
$\mathrm{b}[\varepsilon]$ la + -mente
$\mathrm{b}[\varepsilon]$ lamente
'beautifully' 


\begin{tabular}{|c|c|c|}
\hline $\mathrm{n}[\mathrm{o}] \mathrm{va}+$-inha & $\mathrm{n}[0]$ vinha & 'newDIM, FEM' \\
\hline $\mathrm{n}[\mathrm{o}] \mathrm{va}+$-zinha & $\mathrm{n}[\mathrm{o}]$ vazinha & 'new DIM, FEM' \\
\hline $\mathrm{n}[0] \mathrm{va}+-$ íssima & $\mathrm{n}[\mathrm{o}]$ víssima & 'newSUP, FEM' \\
\hline $\mathrm{t}[\varepsilon] \mathrm{la}+-$ ão & ?t[ع]lão & 'screen $\mathrm{AUG}, \mathrm{MASC}$ ' \\
\hline$[\varepsilon]$ la +-ona & $? \mathrm{t}[\varepsilon]$ lona & 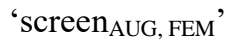 \\
\hline
\end{tabular}

This argument seems to be the criterion which groups the largest number of compositional suffixes. This phenomenon occurs with suffixes -inho, -zinho, -mente and -íssimo, and can affect some cases of augmentatives as well.

2.2 Proposal of true and compositional affixes Considering the criteria analyzed so far, it is noteworthy that some affixes show mixed behavior. One possibility is to imagine that affixes are organized on a gradual scale of prosodic integrity and that some morphological elements are in the way to be prosodized as words. However, if analyzing these elements in a categorical way, we arrive at the following table.

\section{Compositional prefixes}

auto-, ante-, bem-, bi-, contra-, ex-, extra-, hiper-, infra-, macro-, micro-, mono-, neo-, não-, pan-, pós-, pseudo-, pré-, pró-, recém-, semi-, trans, tri-, ultra-, vice-

\begin{tabular}{|c|}
\hline pseudo-, pré-, pró-, recém-, , semi-, trans, tri-, ultra-, vice- \\
\hline Compositional suffixes \\
\hline -inho, -zinho, -mente, -íssimo \\
\hline
\end{tabular}

Chart 2 - List of compositional prefixes and suffixes of BP

\section{Acoustic analysis}

3.1 Theoretical background In this first experimental approach, we intend to investigate the relation between phonetics and phonology: we aim, through acoustic parameters, to find cues to the phonological classification proposed in the previous section, which assumes the existence of two prosodic words in some derivations.

Phonological stress is manifested through different acoustic parameters. There is not one acoustic correlate to identify stress crosslinguistically. Each language uses different patterns to represent prominence. For Brazilian Portuguese, duration is the most reliable acoustic correlate to analyze primary stress.

Massini (1991) shows that in $90 \%$ of the words the stressed syllable is characterized by longer duration. Moraes (1998) also affirms that, if the word is inside a prosodic group, stress is identified by a combination of duration and intensity. Also, Cantoni (2013) shows that duration is capable of differentiating stressed syllables from unstressed ones (and also pretonic from postonic syllables). The parameters F0 and intensity were also relevant for the analysis, but with less power of contrast.

Santana (2014, p. 47) analyzes words with primary and secondary stress and affirms that "the effect of intrinsic duration of segments seems not to affect the analysis of primary stress, since the primarily stressed vowel is extended in a considerable way". Moreover, Arantes and Barbosa (2002) show that duration seems not to be the adequate parameter to indicate the presence of secondary stress in the word. Their analysis for polysyllabic words shows that duration increases towards the stressed position of the word (ARANTES; BARBOSA, 2002). For polysyllabic prosodic nonce words, some initial vowels show cues of greater opening, but, generally, F1 presents more salience values towards the stressed position (ARANTES; BARBOSA, 2008).

3.2 Materials and methods The objective of this pilot experiment is to compare different units of words derived by true and compositional affixes. For this reason, our list of stimuli is composed by monomorphemic words ${ }^{2}$, words with true prefixes, words with compositional prefixes ${ }^{3}$, words with true

2 For simplification of analysis, we combined simple words with words with true affixes, since both represent only one prosodic word. 
suffixes, words with compositional suffixes.

We measured the parameter duration, converted in z-scores, in two different linguistic units: phonological syllables and V-V units (also phonetic syllables, according to Barbosa (2006)). This unit comprehends the segments from the nucleus of a syllable to the nucleus of the next syllable - basically, the vowel, the coda and the next onset. Examples of phonological syllables and V-V units are given in (6).

\section{True affix/Simple word Compositional affix}

Analysis of syllables

[no.'vi.sə] / [no.'vi.sə]

[no. 'vi.no] / [no.' vi.no]
Analysis of V-V units

[n.ov.is.ə] / [n.ov.is.ə]

[n.ov.ij.v] / [n.ov.ij..]

We chose to add the analysis of V-V units to our proposal, because V-V units are more homogeneous due to a "compensation of the intrinsic duration of consonantal segments on immediately precedent vowels" (BARBOSA, 2006, p. 42-44). According to Lucente (2012), based on Barbosa (2006), "V-V units present a durational stability which offers a compensation effect and a homogeneous extension on the duration of segments. Due to these properties, V-V units are used as building blocks to the delimitation of accented groups" (LUCENTE, 2012, p. 99).

Our stimuli were 62 words, which were repeated twice in the carrier sentence Diga X baixinho 'Say X quietly' and twice in short narratives. These stimuli were real words of BP and they were chosen due to phonetic similarity. So, while the group with true affixes/simple words has the words noviça and belina, the group with compositional affixes has the words novinho and belinho.

The participants were 4 men, undergraduate level, 20 to 30 years old. The data were collected in Audacity $(22050 \mathrm{~Hz}, 16-\mathrm{bits})$ in a silent room and the acoustic analysis was conducted in Praat 6.0.40 (BOERSMA; WEENINCK, 2018). All the utterances were labeled in 4 tiers: word, syllable, V-V unit and segment. For the statistical measurements, we used RStudio 1.2.1335 (R CORE TEAM, 2018).

3.3 Main results The comparison between syllable $1^{4}$ (stressed syllables of the base) and syllable 2 (stressed syllable in the affix) in relation to true and compositional suffixes ([bo.'li.nə] x [bo.'li.nə]) is presented in figure 1 .

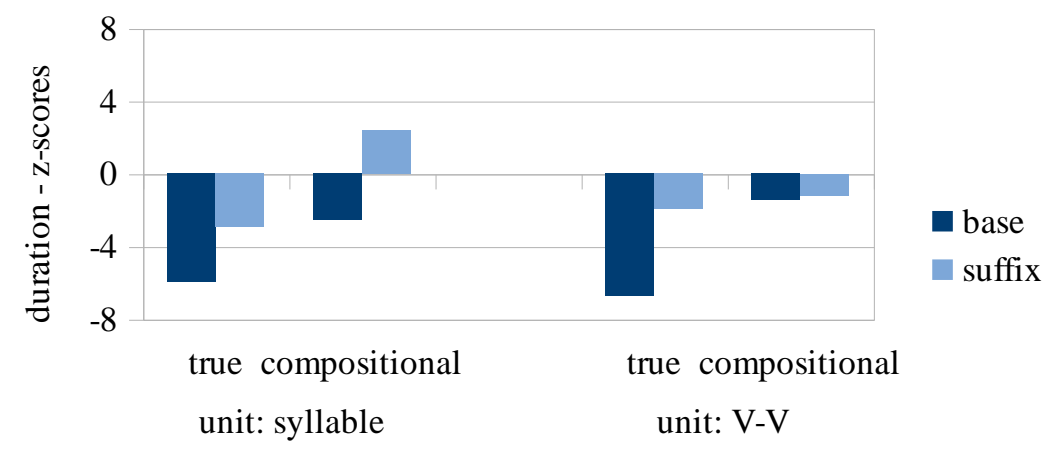

Figure 1 - Duration of syllables and V-V units in words with true and compositional suffixes

In the analysis of syllables - on the left side of the graph -, despite of the fact that compositional words present longer syllables, there is an increase towards the stressed position in both cases. These results do not confirm our hypothesis, since we expected this pattern only for truly derived words. On the other hand, the analysis of phonetic syllables on the right side presents exactly what we expected: the two units of compositional formations present similar duration, as two prominences in the same morphosyntactic word.

In order to verify if some specific pairs present the same pattern than the general results, we compared the means of z-scores for groups of similar words, as in Ulrich (2016).

In the results for the triplet belinha, belinho and belina, we see that we have the same pattern: for

3 The z-scores were calculated with both prefixed and suffixed words; however, for matters of relevance, we will present here only the results for suffixed words.

4 These figures present the results for our trisyllabic words. For this reason, the notation 'base' refers to syllable 1 and the notation 'suffix' refers to syllable 2 . 
syllables, there is increase towards the stressed syllable in the three words, especially in the compositional ones; however, for V-V units, our hypothesis is partially sustained, since we have similar duration in the compositional words and difference only in the simple word (despite the difference is in the unexpected direction).

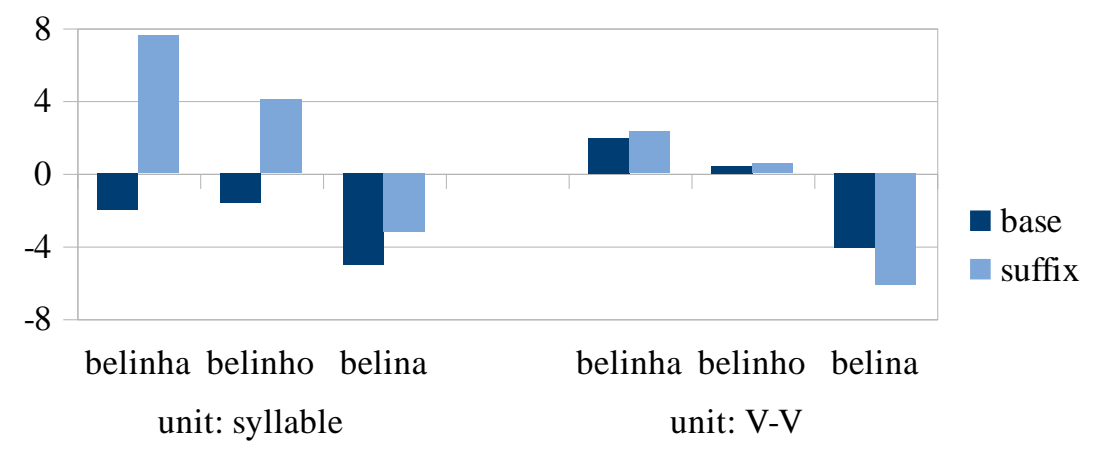

Figure 2 - Duration of syllables and V-V units in belinha, belinho and belina

In other group of similar words - bolinha, bolinho and bolita -, we see that, again, the analysis of syllables is not favorable, despite of not rejecting our hypothesis. However, the analysis of V-V units seems to present results in concordance with the evidence we have from morphophonological processes.

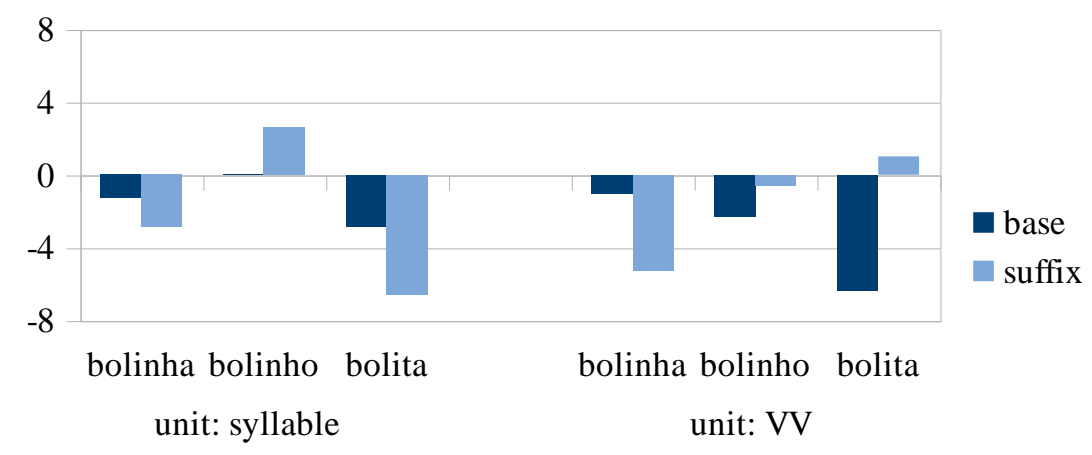

Figure 3 - Duration of syllables and V-V units in bolinha, bolinho and bolita

3.4 Discussion We hypothesized that words derived by true affixes would present characteristics of one prosodic word - longer syllable in the stressed position (MASSINI, 1991; CANTONI, 2013) - and words derived by compositional affixes would present two prominences - one in the base (e.g. bélamente) and one in the affix (e.g. belaménte).

In general, the results confirm only partially our hypothesis. The analysis of syllables and V-V units present different patterns. While syllables, in this pilot experiment, show increase in duration between the base and the suffix for both morphological conditions, V-V units seem to differentiate these two types of formations. These results for syllables are somewhat different from the ones found in Ulrich (2016) and Gilbert (2018).

\section{Eye tracking experiment ${ }^{5}$}

4.1 Theoretical background In this section, we intend to investigate if morphological processing happens differently if we have information of one prosodic word or two prosodic words in only one morphosyntactic word.

In Brazilian Portuguese, some studies defend that we have morphological decomposition ${ }^{6}$ when

5 This methodological step is being developed in a partnership with Concys-UFRGS. We are thankful to Jaime Salas and Arthur Brugger for their support. 
analyzing derived words. Maia, Lemle and França (2007), which served as theoretical-methodological inspiration to our proposal of analysis, seek to understand if words are stored as units or if morphemes are accessed during the processing. The authors use two experimental paradigms.

The first one is based on a chromatic identification task to demonstrate the automaticity of initial phases of reading processing. The authors conclude that the subjects could recognize with more accuracy and less reaction time the color of the target letter in conditions with morphemic division, regardless of whether the morpheme was attached to a word (compositional meaning) or to a root (arbitrary meaning) ${ }^{7}$.

The second experiment involves an eye tracking task during the reading of the same words. The goal is to monitor the fixations and saccades in the first eye scan and also in regressive movements (MAIA; LEMLE; FRANÇA, 2007, p. 2). The authors saw that the stimuli in the condition in which morphemes are attached to words require more fixation time, attesting the increased activity required by morphological decomposition. The conclusion is that the experiments seem to have indicated the availability of two types of lexical access for isolated words in BP: direct access and morphological decomposition.

Maia and Ribeiro (2012), in a lexical decision task with eye tracking, investigate the hypothesis that there is more Total Fixation Duration (TFD) and saccades on suffixed words and nonce words than on monomorphemic words and nonce words. The results show that Total Fixation Duration on words with suffixes was significantly longer that in its monomorphemic correspondents. In general, suffixed words exhibited more saccades than monomorphemic words. Also, words were accessed more quickly that nonce words. The authors conclude that decomposition models (full parsing) can account on the results, but double route models are not excluded as possibilities of analysis.

Regarding not only morphological characteristics, but also its prosodic structure, Vannest and Boland (1999) examine the relation between a proposal on Lexical Morphology and lexical access. They suggest that productive, phonologically neutral, semantically transparent "level 2" suffixes - equivalent to compositional suffixes - are decomposed for analysis in some cases, but that words with idiosyncratic, structure-changing, semantically opaque "level 1" suffixes are not.

4.2 Materials and methods Considering that decomposition happens in multi-morphemic words and that the processing of compositional affixes can be different than true affixes, we investigate if there are cues for differences in processing types of affixes in BP through an eye tracking experiment with a lexical decision task.

Our dependent variables are i) total time of fixation (ms); ii) accuracy (\%); iii) reaction time (ms). We take into account the type of morphological formation (if word with true prefix, word with compositional prefix, word with true suffix, word with compositional suffix) and the reality of the word.

In this pilot experiment, we analyzed 64 stimuli (32 words and 32 nonce words) -8 words for each type of morphological formation. Again, the words were chosen or created based on phonetic similarities, so we have, for example, the real words bolita (word / true suffix) and bolinha (word / compositional suffix) and the nonce words dorida (nonce word / true suffix) and dorinha (nonce word / compositional suffix). The reason for distributing the stimuli according to phonetic similarity is that we have the same number of syllables (and usually the number of letters) for each condition.

The participants were 7 men, undergraduate level, from 20 to 30 years old. The silent reading with eye tracking, followed by a lexical decision task (is it a word of BP?) was created and reproduced by Psychopy 3.1 (PEIRCE; MACASKILL, 2018.). The eye tracker equipment was a Tobii 4C eye tracker and the statistical analysis was done by RStudio 1.2.1335 (R CORE TEAM, 2018).

4.3 Main results In table 1, we see that the means of fixations per condition are represented by close numbers. However, total time of fixations is increased in conditions with compositional affixes.

6 They mention that maybe morphological decomposition is not the only way to access our lexicon. However, it is one the possibilities showed through experimental approaches.

7 Different from our hypothesis of morphological attachment, the authors consider that all the transparent affixes are attached to words. The condition MR (morpheme and root) is used only for non-transparent formations, as in caninha, which refers to an alcoholic beverage, and not to diminutive of cana 'cane'. 


\begin{tabular}{|c|c|c|c|c|c|}
\hline \multirow{2}{*}{} & \multicolumn{2}{c|}{ Prefixes } & \multicolumn{2}{c|}{ Suffixes } \\
\hline Real words & Fixations & 6.7 & 6.6 & 5.5 & 6.6 \\
\hline & Total time & $1404 \mathrm{~ms}$ & $1623 \mathrm{~ms}$ & $1450 \mathrm{~ms}$ & $1587 \mathrm{~ms}$ \\
\hline Nonce words & Fixations & 10.6 & 10.3 & 8.1 & 8 \\
\hline & Total time & $2385 \mathrm{~ms}$ & $2336 \mathrm{~ms}$ & $1877 \mathrm{~ms}$ & $2075 \mathrm{~ms}$ \\
\hline
\end{tabular}

Table 1 - Number of fixations and total time of fixations for each condition

This first result for time of fixation can suggest that words with true and compositional affixes are accessed in different ways.

Also, if we look at similar words (e.g. bolinha, bolita), sometimes we have the same number of fixations, but these fixations are in different places in the words. The heatmaps below show the difference between bolinha 'ball.DIm' - compositionally affixed - and bolita 'ball.DIM' - truly affixed. In relation to the mean of fixations for all informants, both have 4 fixations with total time between 1182ms and 1349ms.
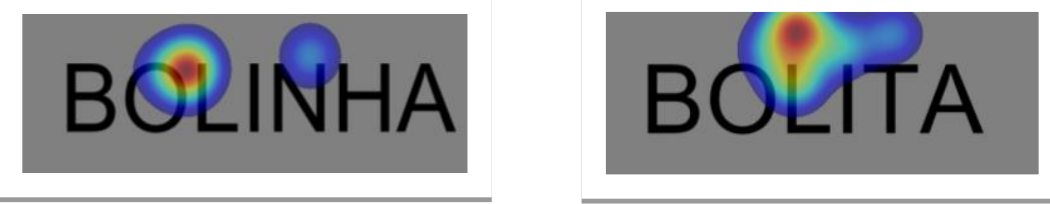

Figure 4 - Heatmaps of bolinha and bolita (Inf C)

Moreover, the scanpaths in figure 2 exhibit the ordering of saccades (represented by lines) and fixations (represented by circles) in the same words - the example is taken from the same informant. We can note that in bolinha 'ball.DIM', there is a regressive saccade in the position where we can find the stress in the base.

\section{BOL!NHA}

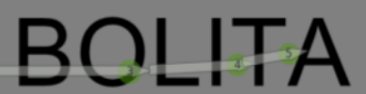

Figure 5 - Scanpaths of bolinha and bolita $(\operatorname{Inf} \mathrm{C})$

In fact, only the number of fixations per conditions seems not to be important. For this reason, in further steps of this analysis, we intend to analyze deeply the exact points of fixations for each word.

Regarding the lexical decision task, we measured accuracy (\%) and reaction time (ms). Considering the analysis of accuracy, we see that, in general, we have more wrong answers in the conditions with compositional affixes.

\begin{tabular}{|c|c|c|c|c|}
\hline \multirow{2}{*}{} & \multicolumn{2}{|c|}{ Prefixes } & \multicolumn{2}{c|}{ Suffixes } \\
\cline { 2 - 5 } & True & Compositional & True & Compositional \\
\hline Real words & $54 / 64-84,3 \%$ & $53 / 64-82,8 \%$ & $52 / 64-81,2 \%$ & $47 / 64-73,4 \%$ \\
\hline None words & $45 / 64-70,3 \%$ & $47 / 64-73,4 \%$ & $51 / 64-79,6 \%$ & $47 / 64-73,4 \%$ \\
\hline
\end{tabular}

Table 2 - Accuracy in lexical decision task

For reaction time, stimuli with compositional affixes present longer times than true affixes. Considering that all nonce words had longer reaction times than real words, we decided to analyze only real 
words. Figure 6 shows that compositional words had longer reaction times that true words.

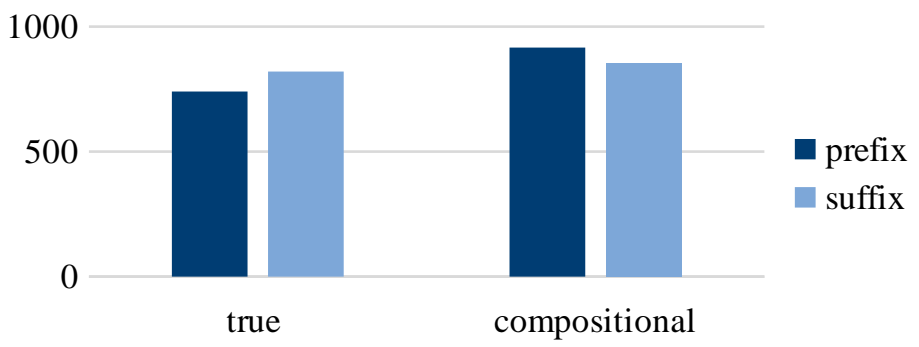

Figure 6 - Reaction time (ms) for real words

4.4 Discussion Our results from the pilot experiment suggest that the morphological processing of truly and compositionally derived words is different, in concordance with Vannest and Boland (1999). All the dependent variables in this experiment indicate a higher cost of processing in compositional forms.

This result can be explained by the prosodic independence and complexity of compound-like structures. Despite of having only one morphosyntactic word, these affixes do not behave as a prototypical affix in the language.

\section{Final remarks and further steps}

This study describes an analysis of two types of affixes in BP. We show that compositional affixes can occur in isolation, are attached to the stem/word, are more peripheral in relation to the root and are more productive and transparent than true affixes. Phonologically, they exhibit final raising, categorical maintenance of nasalization of its base and preservation of vowel quality in the derived form. Moreover, they act as a barrier to the application of vowel harmony, assibilation and velar softening.

In order to sustain empirically that these two classes behave differently in BP, we conducted two experiments. The acoustic analysis of duration in syllables showed increase between the base and the suffix for both morphological conditions, but the analysis of other unit, called phonetic syllable or V-V unit, seemed to differentiate these two types of formations. Furthermore, compositional derivatives presented longer total time of fixation in the eye tracking analysis and longer and less accurate answers in the lexical decision task. These partial results seem to contribute to the idea that there are two different classes of affixes and there are empirical cues to sustain this division.

As an ongoing research, the next steps include the collection of data from a larger group of informants and a greater control of our prefixed and polysyllabic suffixed words. With more control on our stimuli, we can account for finding evidence for both edges of the word. However, we should mention that, even if our results were not favorable to our hypothesis, the questions outlined here would remain, considering the phonological properties of these affixes.

\section{References}

Arantes, Pablo; Barbosa, Plínio Almeida (2002) Acentuação secundária em Português Brasileiro à luz do modelo dinâmico do ritmo: um estudo piloto. Proceedings of I Congresso Internacional de Fonética e Fonologia/VII Congresso Nacional de Fonética e Fonologia. Belo Horizonte.

Arantes, Pablo; Barbosa, Plínio Almeida (2008) F1 and Spectral Correlates of Secondary Stress in Brazilian Portuguese. In: Barbosa, Plínio Almeida; Madureira, Sandra; Reis, César (ed.) Proceedings of the Speech Prosody 2008 Conference. Campinas: Editora RG/CNPq.

Barbosa, Plínio Almeida (2006) Incursões em torno de ritmo da fala. Campinas: Editora Pontes.

Bachrach, Asaf; Wagner, Michael (2007) Syntactically Driven Cyclicity vs. Output-Output Correspondence: The Case of Adjunction in Diminutive Morphology. In.: U. Penn Working Papers in Linguistics, v. 10.1.

Bisol, Leda (1981) Harmonia vocálica, uma regra variável. Doctoral dissertation. Federal University of Rio de Janeiro.

Cantoni, Maria Mendes (2013) O acento no português brasileiro: uma abordagem experimental. Doctoral dissertation. Federal University of Minas Gerais.

Farias, Letícia Stander (2012) A assibilação na formação de palavras em português: análise via teoria da marcação comparativa. Doctoral dissertation. Pontificial Catholic University of Rio Grande do Sul.

Gilbert, Madeline (2018) Stress and Morphological Complexity in Brazilian Portuguese. Poster on Annual Meeting on 
Phonology 2018.

Lee, Seung-Hwa (1995) Morfologia e fonologia lexical do Português do Brasil. Doctoral dissertation. University of Campinas.

Lucente, Luciana (2012) Aspectos dinâmicos da fala e da entoação no português brasileiro. Doctoral dissertation. University of Campinas.

Massini, Gladis (1991) A duração no estudo do acento e ritmo do português. Master thesis. University of Campinas.

Menuzzi, Sérgio (1993) On the Prosody of the Diminutive Alternation -inho/-zinho in Brazilian Portuguese. HIL/Leiden University, 1993.

Moraes, João (1998) Intonation in Brazilian Portuguese. In: Hirst, Daniel; Di Cristo, Albert (orgs.) Intonation System. Cambridge: Cambridge University Press, p. 179-193.

Moreno, Cláudio (1977) Os Diminutivos em -inho e -zinho e a Delimitação do Vocábulo Nominal no Português. Master thesis. Federal University of Rio Grande do Sul.

Moreno, Cláudio (1997) Morfologia nominal do Português: um estudo de Fonologia Lexical. Doctoral dissertation. Pontificial Catholic University of Rio Grande do Sul.

Nespor, Marina; Vogel, Irene (1986) Prosodic phonology. Dordrecht: Foris Publications.

Peirce, Jonathan; MacAskill, Michael (2018) Building Experiments in PsychoPy. London: Sage. 2018.

Santana, Beatriz Pires (2014) O acento secundário no português brasileiro: resultados de um experimento piloto. Versalete, v. 2, no 3, Curitiba, jul-dez.

Schwindt, Luiz Carlos (1995) A harmonia vocálica em dialetos do sul do país: uma análise variacionista. Master thesis. Pontificial Catholic University of Rio Grande do Sul.

Schwindt, Luiz Carlos (2000) O prefixo no Português Brasileiro: análise morfofonológica. Doctoral dissertation. Pontificial Catholic University of Rio Grande do Sul.

Schwindt, Luiz Carlos (2008) Revisitando o estatuto prosódico e morfológico de palavras prefixadas do PB em uma perspectiva de restrições. Alfa, v.52(2), p. 391-404.

Schwindt, Luiz Carlos (2013a) Palavra fonológica e derivação em português brasileiro: considerações para a arquitetura da gramática. In: Bisol, Leda; Collischonn, Gisela (org.) Fonologia: teorias e perspectivas. $1^{a}$ ed. Porto Alegre: EDIPUCRS, p. 15-28.

Ulrich, Camila Witt (2016) A neutralização de vogais médias pretônicas e a formação de palavras complexas em PB: o caso dos sufixos -inho/-zinho, -mente e -íssimo. Master thesis. Federal University of Rio Grande do Sul.

Vannest, Jennifer; Boland, Julie (1999) Lexical Morphology and Lexical Access. Brain and Language volume 68. 